OPEN ACCESS

Citation: Kolawole O.S, Abdulrahaman A.A., Chukwuma E.C., Jimoh M.A. (2021) A numerical approach to the taxonomy of some species of the Subtribe Cassiinae in Nigeria. Webbia. Journal of Plant Taxonomy and Geography 76(1): 97-108. doi: 10.36253/jopt-10036

Received: November 19, 2020

Accepted: January 20, 2021

Published: April 27, 2021

Copyright: (C) 2021 Kolawole O.S, Abdulrahaman A.A., Chukwuma E.C., Jimoh M.A. This is an open access, peerreviewed article published by Firenze University Press (http://www.fupress. com/webbia) and distributed under the terms of the Creative Commons Attribution License, which permits unrestricted use, distribution, and reproduction in any medium, provided the original author and source are credited.

Data Availability Statement: All relevant data are within the paper and its Supporting Information files.

Competing Interests: The Author(s) declare(s) no conflict of interest.

Editor: Alessio Papini

ORCID

OSK: https://orcid.org/0000-0001-6366-

3707

AAA: https://orcid.org/0000-0001-8974-

5807

ECC: https://orcid.org/0000-0002-4154-

283X

MAJ: https://orcid.org/0000-0003-42114535

\section{A numerical approach to the taxonomy of some species of the Subtribe Cassiinae in Nigeria}

\author{
Opeyemi Saheed Kolawole ${ }^{1,2, *}$, Abdullahi Alanamu Abdulrahaman ${ }^{2}$, \\ Emmanuel Chukwudi Chukwuma ${ }^{3}$, Mahboob Adekilekun Jimoh 4 \\ ${ }^{1}$ Department of Biological Sciences, Federal University of Kashere, Gombe State, Nigeria \\ ${ }^{2}$ Wood Technology Laboratory, Department of Plant Biology, University of Ilorin, Nigeria \\ ${ }^{3}$ Forest Herbarium Ibadan (FHI), Forestry Research Institute of Nigeria, Ibadan, Oyo \\ State, Nigeria \\ ${ }^{4}$ Department of Plant Biology, Osun State University, Osogbo, Nigeria \\ ${ }^{\star}$ Corresponding author. E-mail: kolawolesaheed@fukashere.edu.ng
}

\begin{abstract}
Twelve morphological parameters from the leaves, fruits, and pedicel of fifteen (15) species of the subtribe Cassiinae were studied using the methods of numerical taxonomy. Characters such as leaflet length, leaflet width, and leaflet length/width ratio contributed significantly in the delimitation of the species studied. While $C$. italica and Ch. mimosoides are the most closely related taxa, C. fistula and C. singueana appear to be the most distantly related as reflected by the cluster coefficients. Further illustrations as revealed by the dendrogram and scatter plot generated placed the 15 studied species into three groups. While we acknowledge the relevance of phylogenetic analysis in taxonomic studies as it is in recent times, we strongly support the application of numerical taxonomy to compliment findings.
\end{abstract}

Keywords: Custer analysis, fruits, Cassiinae, leaves, PCA, Numerical taxonomy.

\section{INTRODUCTION}

Cassia Linn. is a very large genus in the subtribe Cassiinae, which is comprised of about 500 to 600 species (Airy-Shaw 1973; Saheed and Illoh 2010). It is the largest genera in the sub family Caesalpinioideae, and ranks among the 25 largest genera of the dicotyledons as reported by Irwin and Turner (1960). In West Africa, it consists of about 22 species aside from the introduced or cultivated species (Hutchinson and Dalziel 1958; Saheed and Illoh, 2010; Kolawole 2017). The genus includes trees, shrubs, and herbs and has a pantropical distribution, but very few in Asia (Irwin and Barneby 1981). It is characterized by the possession of evenly-pinnate leaves with stipules of various types; flowers slightly irregular, solitary, racemose or paniculate; stamens 5 or 10, frequently unequal; fruits sessile or stalked, terete or flattened and often partitioned crosswise (Irwin and Barneby 1982; Larsen et al. 1984). Bentham (1871) in his revision of the genus indicated that it is comprised of three distinct groups. Three separate genera, i.e. Cassia sensu 
stricto, Chamaecrista Moench, and Senna Mill. were recognized based on characters of filaments and the presence or absence of bracteoles (Irwin and Barneby 1981, 1982; Lock 1988; Larsen 1993; Hou et al. 1996; Mabberley 1997; Singh 2001). These three genera belong to the tribe Cassieae and subtribe Cassiinae of the Leguminosae-Caesalpinioideae.

Numerical taxonomy or taximetrics refers to the application of various mathematical procedures to numerically encoded character state data for plant species under study. This approach results in a classification based on a greater number of characters from sets of data (multivariate) to develop an entirely phenetic classification of maximum predictivity as put by Pandey and Misra (2009).

Morphometric techniques have long been established as valuable tools for exploring the development, population differentiation, and systematics of plants (Bookstein et al. 1985; Wiens 2000; Forey and MacLeod 2002; Jensen 2003; Bateman and Rudall 2006). Authors have also applied this techniques in the study of Ficus species (Sonibare et al. 2004), Acalypha species (Soladoye et al. 2008), Indigofera species (Soladoye et al. 2010a), Jatropha species (Kolawole et al. 2016), Berlinia species (Chukwuma et al. 2016), accessions of Senna didymobotrya (Jeruto et al. 2017) etc. In morphometric studies however, diagnostic characters are essential. These characters are constant within a group but vary between groups and could be used to identify natural plant groups from several others of similar ranking (Davis and Heywood 1963; Kent and Coke 1992; Jeruto et al. 2017). Morphological characters are helpful in the identification and delimitation of taxa and genera into tribes and subfamilies (Yousuf et al. 2008), and these characters have been recognized as basic criteria for identification and authentication of plants (Sultana et al. 2011).

Boonkerd et al. (2005) investigated some species of Cassia L. that were difficult to determine due to morphological complexes. In order to investigate the taxonomic status of this genus, morphological characters from 508 specimens of 18 taxa were analyzed using numerical cluster analysis and canonical discriminate analysis. A total of 32 vegetative and reproductive morphological characters were focused on in this analyzes. As a result of numerical cluster analysis, they suggested Cassia s.l. can be separated into four groups, viz. Chamaecrista, Senna alata, Senna, and Cassia s.str. with an average taxonomic distance of 1.30. His result was supported by Irwin and Barneby's (1981) classification. Moreover, the filament length, fruit length, and ovary stalk are useful quantitative characters for discriminating the three genera and further grouping.
Many members of the subtribe Cassiinae are economically important. Senna species could be stimulant laxatives and used for the treatment of constipation (Bradley 1992). Significant inhibitory activity of Senna species against leukemia has also been documented in mice as reported by Jimoh et al. (2013). In Nigeria, the plants are used for treating eczema and other skin defects caused by fungal infections (Akinremi et al. 2000). The leaves are also prepared into vegetable soup for smallpox and measles. The leaves of Senna podocarpa (Guill. and Per.) Lock. are extensively known for their anti-gonorrhoeal and purgative properties as well as being a guinea worm and sore-healing remedy among the Igbos in Nigeria. A concoction of the fresh leaves is used in the treatment of syphilis (Gomes et al. 1997), herpes, and swine fever (Silva et al. 1997) and as purgative and for repelling or killing insects such as termites, bed bugs and mosquitoes (Elujoba et al. 1999).

Taking into consideration the close affinities existing between members of the sub-tribe Cassiinae, the present study aimed at using numerical methods to examine the differences and similarities in the morphological characters used to delimit some species of this legume group. The chief goal of our study is to determine the traits that would contribute strongly to the delimitation of the taxa based on their similarities.

\section{MATERIALS AND METHODS}

\section{Selection of species}

Fifteen species of the subtribe Cassiinae were selected based on availability, and employed in this study. These include Cassia fistula L., Cassia italica Mill., Cassia sieberiana DC., Cassia singueana (Del.) Lock., Chamaecrista mimosoides (L.) Greene, Chamaecrista rotundifolia (Pers.) Greene, Senna alata (L.) Roxb, Senna biflora L., Senna hirsuta (L.) Irwin \& Barneby, Senna obtusifolia (L.) Irwin \& Barneby, Senna occidentalis (L.) Link., Senna podocarpa (Guill. \& Per.) Lock, Senna siamea (Lam.) Irwin \& Barneby, Senna sophera (L.) Roxb. and Senna spectabilis (DC.) Irwin \& Barneby.

Plant collection, preparation and authentication of herbarium specimens

Field trips were undertaken to different ecological zones of Nigeria for the collection of available species of Cassiinae (Table 1). Fresh specimens for the study were collected from a variety of sources such as open vegetation, roadsides, private gardens, and bushy areas. Upon 
Table 1. Voucher specimens prepared for the Cassinae species studied.

\begin{tabular}{|c|c|c|c|c|c|}
\hline $\mathrm{S} / \mathrm{N}$ & Species & Places of Collection/Locality & Voucher number & Latitude $(\mathrm{N})$ & Longitude (E) \\
\hline 1 & Cassia fistula Linn. & $\begin{array}{l}\text { Beside Block 10, UNILORIN main Campus, } \\
\text { Ilorin }\end{array}$ & FHI 109792 & 8.496642 & 4.542143 \\
\hline 2 & Cassia italica Mill. & GSU campus, Gombe Metropolis, Gombe State & FHI 109966 & 10.306208 & 11.164688 \\
\hline 3 & Cassia sieberiana DC. & $\begin{array}{l}\text { Beside Sports Centre, OAU Campus, Ile Ife, } \\
\text { Osun State. }\end{array}$ & FHI 109967 & 7.116667 & 3.616667 \\
\hline 4 & Cassia singueana (Del.) Lock. & $\begin{array}{l}\text { Along Kashere -Alhaleri road, Kashere, Gombe } \\
\text { State. }\end{array}$ & FHI 109965 & 9.9 & 11.016667 \\
\hline 5 & $\begin{array}{l}\text { Chamaecrista mimosoides (L.) } \\
\text { Greene }\end{array}$ & Ori Eru Village, Asa LGA, Kwara State. & FHI 109868 & 8.422145 & 4.44047 \\
\hline 6 & $\begin{array}{l}\text { Chamaecrista rotundifolia (Pers.) } \\
\text { Greene }\end{array}$ & $\begin{array}{l}\text { Tunfure Cattle village, Along Airport Road, } \\
\text { Gombe. }\end{array}$ & FHI 109788 & 10.619407 & 13.075471 \\
\hline 7 & Senna alata (L.) Roxb & Sekona village, Ede South LGA, Ede & FHI 109787 & 7.65824 & 4.457619 \\
\hline 8 & Senna biflora Linn. & $\begin{array}{l}\text { Infront of Olu of Akoda Palace, Akoda, Ede, } \\
\text { Osun State }\end{array}$ & FHI 109867 & 7.31443 & 4.263754 \\
\hline 9 & Senna hirsuta (L.) Irwin \& Barneby & $\begin{array}{l}\text { In front of FUOYE main gate, Oye Ekiti, Ekiti } \\
\text { State }\end{array}$ & FHI 109869 & 7.79976 & 5.320353 \\
\hline 10 & $\begin{array}{l}\text { Senna obtusifolia (L.) Irwin \& } \\
\text { Barneby }\end{array}$ & $\begin{array}{l}\text { Along Pindinga- Kashere road, Akko LGA, } \\
\text { Gombe State }\end{array}$ & FHI 109790 & 9.813505 & 10.92536 \\
\hline 11 & Senna occidentalis (L.) Link. & $\begin{array}{l}\text { Gaa Imam Area, Along Ajase-Ipo Road, Ilorin, } \\
\text { Kwara State }\end{array}$ & FHI 109866 & 8.5 & 5 \\
\hline 12 & $\begin{array}{l}\text { Senna podocarpa (Guill. \& Per.) } \\
\text { Lock }\end{array}$ & $\begin{array}{l}\text { U I Botanical Nursery, Dept. of Botany, U I, } \\
\text { Ibadan. }\end{array}$ & FHI 109870 & 7.4477245 & 3.8967116 \\
\hline 13 & $\begin{array}{l}\text { Senna siamea (Lam.) Irwin \& } \\
\text { Barneby }\end{array}$ & Behind Federal High Court, GRA, Gombe State. & FHI 110012 & 10.719038 & 13.356643 \\
\hline 14 & Senna sophera (L.) Roxb. & $\begin{array}{l}\text { Along Agah Ganmo Road, Ifelodun LGA, Kwara } \\
\text { State }\end{array}$ & FHI 109785 & 8.546826 & 5.090122 \\
\hline 15 & $\begin{array}{l}\text { Senna spectabilis (DC.) Irwin \& } \\
\text { Barneby }\end{array}$ & $\begin{array}{l}\text { In front of LAUTECH Senate Building, } \\
\text { Ogbomoso, Oyo State. }\end{array}$ & FHI 109965 & 8.1700515 & 4.2664348 \\
\hline
\end{tabular}

collection of fresh plants, voucher specimens were prepared according to established protocols (Soladoye et al. 2010a,b; Kolawole et al. 2016; Chukwuma et al. 2016), and authenticated at the Forest Herbarium Ibadan (FHI) while the duplicates were deposited at Ilorin University Herbarium. FHI is listed in Holmgren et al. (1990).

\section{MORPHOMETRIC ANALYSIS}

This was based on morphological measurements from fresh and previously deposited herbarium specimens representing 15 species within the tribe Cassinae. Field observations were made from individual species of several populations across the country. Representative photographs of individual plant species were taken using a 16.0 megapixels Sony digital camera. Specifically, twenty-five accessions of each species were examined for their morphological characteristics. Some traits which were difficult to assess accurately or were unsuitable for rapid and accurate scoring were eliminated. Quantitative mor- phological data such as leaflet length, leaflet width, petiole width, petiole length, pedicel length, pedicel width, fruit length, fruit width, etc., were taken using thread, a standard metre rule and an electronic digital calliper (Titan 3105) graduated in millimetres (later converted to centimetres). These measurements were compiled for each Operational Taxonomic Unit (OTU) and the corresponding mean values of the recorded characters were carefully calculated and keyed into a Microsoft Excel spreadsheet. They were thereafter subjected to Principal Components Analysis (PCA) and Cluster Analysis using Paleontological Statistics (PAST) and SPSS 20.0 statistical software.

\section{RESULTS}

\section{Species distribution}

Cassinae species exhibit a wide distribution accros all geo-ecological zones of Nigeria but appears to be 


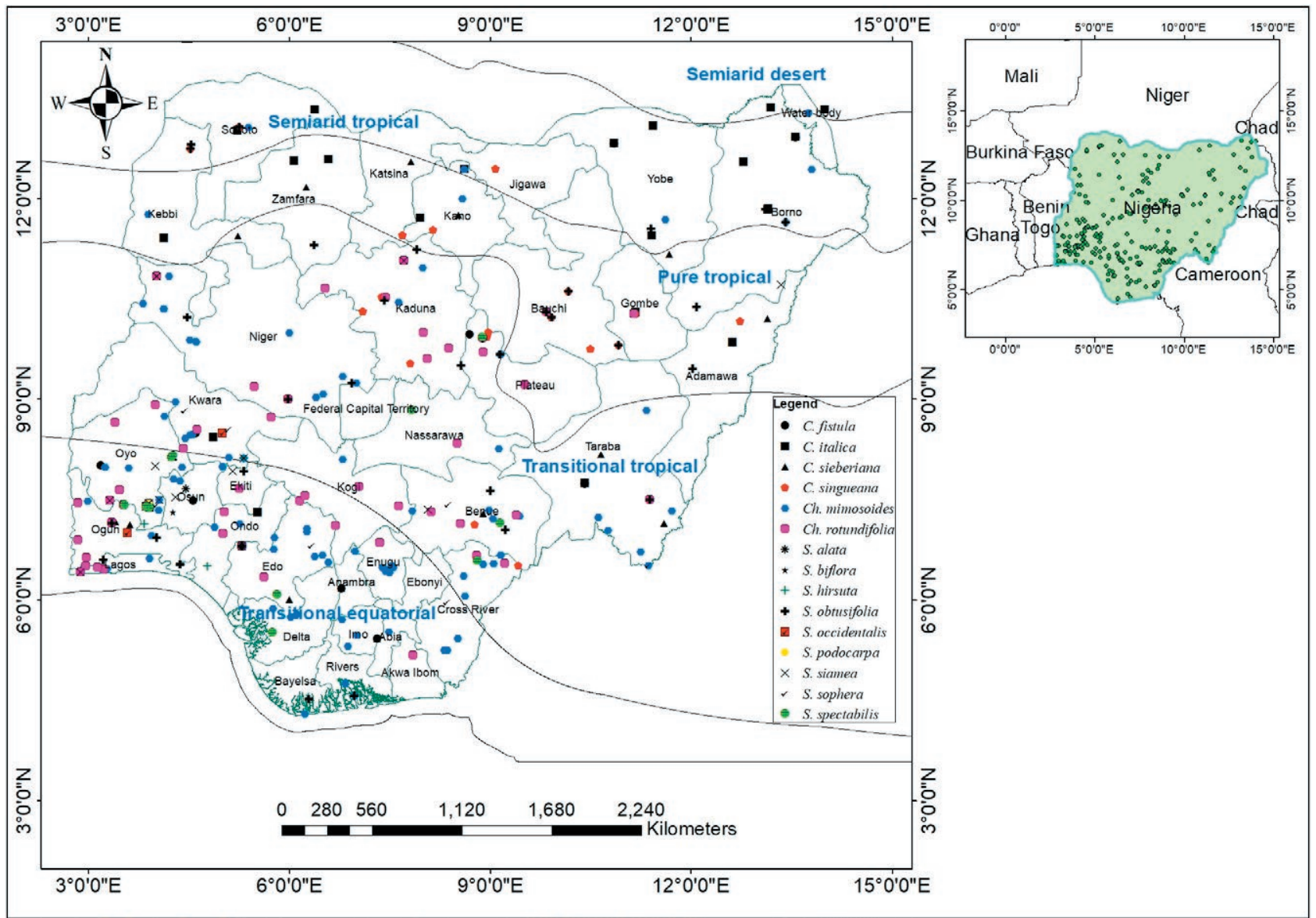

Figure 1. Distribution of the subtribe Cassinae in Nigeria.

more abundant in southern Nigeria which is characterised by a transitioal equatorial climatic zone (Figure 1). This area recieves more rainfall that other zones, and may profer a more suitable habitat for the growth of the species studied.

\section{Quantitative traits of the species}

The morphological appearance of each representative species is shown in Figure 2, while the quantitative features are listed in Table 2. The highest leaflet length was observed in Senna alata $(12.73 \pm 3.29 \mathrm{~cm})$ while the lowest was recorded in Chamaecrista rotundifolia $(1.62 \pm 0.13 \mathrm{~cm})$. The least leaflet width was recorded in Chamaecrista mimosoides $(0.59 \pm 0.02 \mathrm{~cm})$ while the highest was observed in Cassia fistula (6.69 \pm 0.51 $\mathrm{cm})$. Leaflet length/width ratio measured the highest in Chamaecrista mimosoides, with a mean value of $6.95 \pm$ $1.33 \mathrm{~cm}$ while the least mean value of $1.02 \pm 0.09 \mathrm{~cm}$ was observed in Chamaecrista rotundifolia.
The longest petiole was observed in Senna podocarpa $(9.1 \pm 0.75 \mathrm{~cm})$ while the shortest was obtained in Senna siamea $(0.24 \pm 0.05 \mathrm{~cm})$. The highest and the least petiole width was obtained in Cassia italica $(2.66 \pm 0.44 \mathrm{~cm})$ and Senna siamea $(0.09 \pm 0.01 \mathrm{~cm})$ respectively. The least ratio of petiole length and width was obtained in Cassia italica $(0.89 \pm 0.19 \mathrm{~cm})$ the highest is recorded in Senna sophera $(27.45 \pm 2.13 \mathrm{~cm})$.

Furthermore, Cassia sieberiana had the longest fruit $(53.19 \pm 3.12 \mathrm{~cm})$ while the shortest was observed in Chamaecrista rotundifolia $(2.92 \pm 0.22 \mathrm{~cm})$. Conversly, the highest fruit width was recorded in Cassia sieberiana $(1.44 \pm 0.09 \mathrm{~cm})$ and the least was in Chamaecrista rotundifolia $(0.34 \pm 0.02 \mathrm{~cm})$. The highest and least ratio of the fruit length and width were recorded in Senna obtusifolia $(38.96 \pm 0.02 \mathrm{~cm})$ and Senna biflora $(4.54 \pm 0.39 \mathrm{~cm})$ respectively.

The longest pedicel was observed in Cassia sieberiana $(3.97 \pm 1.96 \mathrm{~cm})$ while the shortest was in Senna biflora $(0.28 \pm 0.35 \mathrm{~cm})$. The highest pedicel width was recorded in Senna occidentalis $(0.27 \pm 0.14 \mathrm{~cm})$ and the 

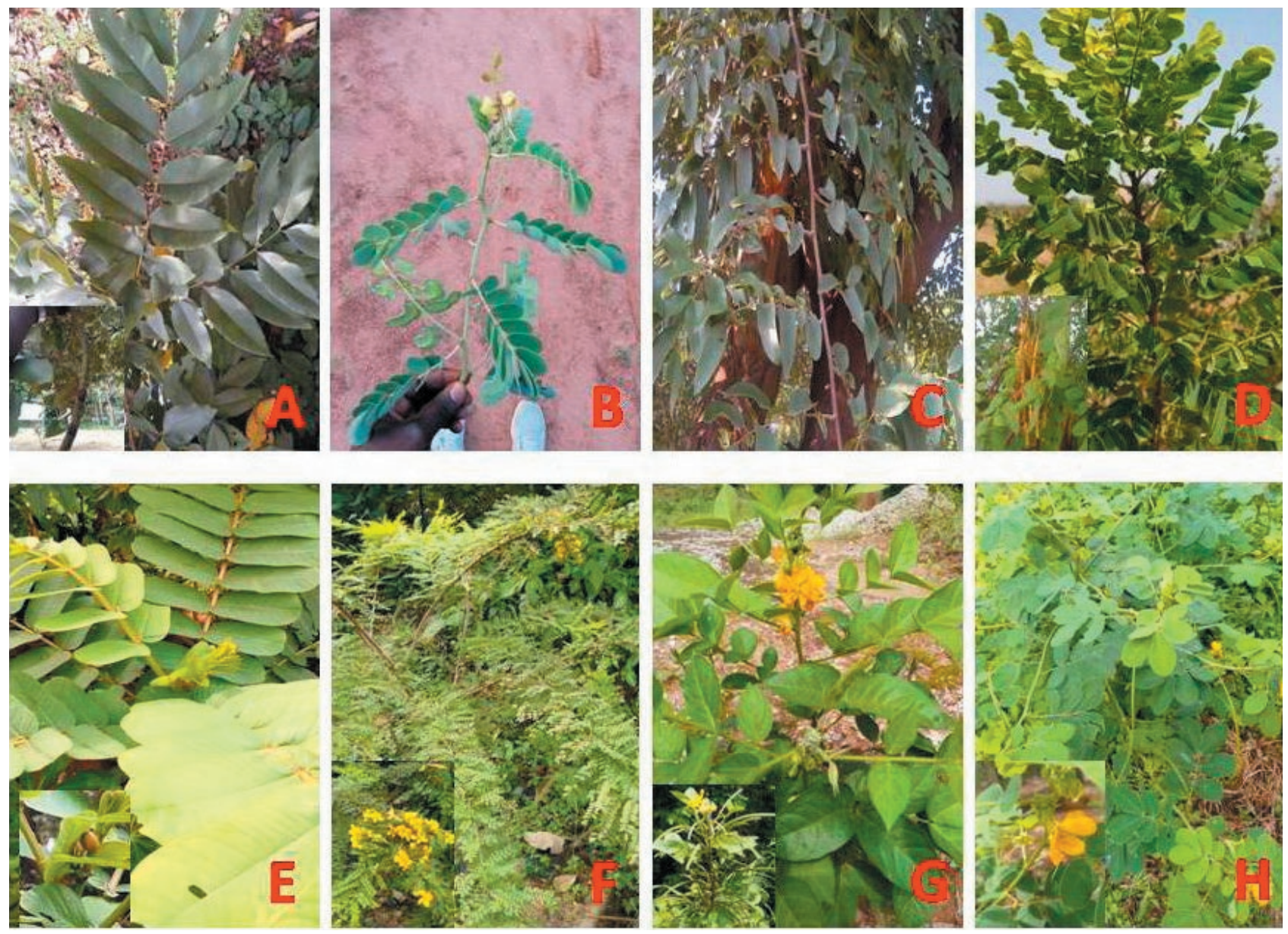

Figure 2: Morphology of the species of the subtribe Cassinae studied. A- Cassia fistula, B- Cassia italica, C- Cassia sieberiana, D- Cassia singueana, E- Senna alata, F- Senna biflora, G- Senna hirsuta, H- Senna obtusifolia.

least was in both Cassia fistula and Senna spectabilis with $0.02 \pm 0.04$ and $0.02 \pm 0.01$ respectively. The highest pedicel length/width ratio was observed in Cassia singueana $(83.04 \pm 7.31 \mathrm{~cm})$, while the least wasin Senna biflora $(2.29 \pm 0.52 \mathrm{~cm})$ (Table 2).

Cluster analysis of the studied species of subtribe Cassiinae using morphological characters

Similarity indices for the studied species of the subtribe Cassiinae based on euclidean distance for the morphological traits is presented in Table 3. The least coefficient was observed between C. italica and Ch. mimosoides (11.52), followed by S. alata and S. occidentalis (11.96), while the highest were observed between $C$. singueana and S. biflora (82.85). The species are divided into three (3) clusters (Figure 3, Table 4). The first cluster comprises 11 species, while the second and third clus- ters are represented by 2 species each. The result of the agglomeration schedule (Table 4) showed that the most closely related taxa are $C$. italica and $C h$. mimosoides with a coefficient of 132.743 while the most distantly related are C. fistula and C. singueana with a coefficient of 4225.493. The variance in the observed morphological traits using principal component analysis is also presented in Table 5. As revealed, only four (4) components contributed $80.5 \%$ of the total variance, while the remaining eight (8) were uninformative and contributed insignificantly to the delimitation of the taxa studied.

The first component is most highly correlated with leaflet length, the second is most correlated with petiole width, the third with pedicel length/pedicel width ratio while the fourth component is most highly correlated with fruit length (Table 6a). When components are rotated, the first is still most highly correlated with leaflet length. The second is most highly correlated with fruit length/fruit width ration, the third with pedicel 

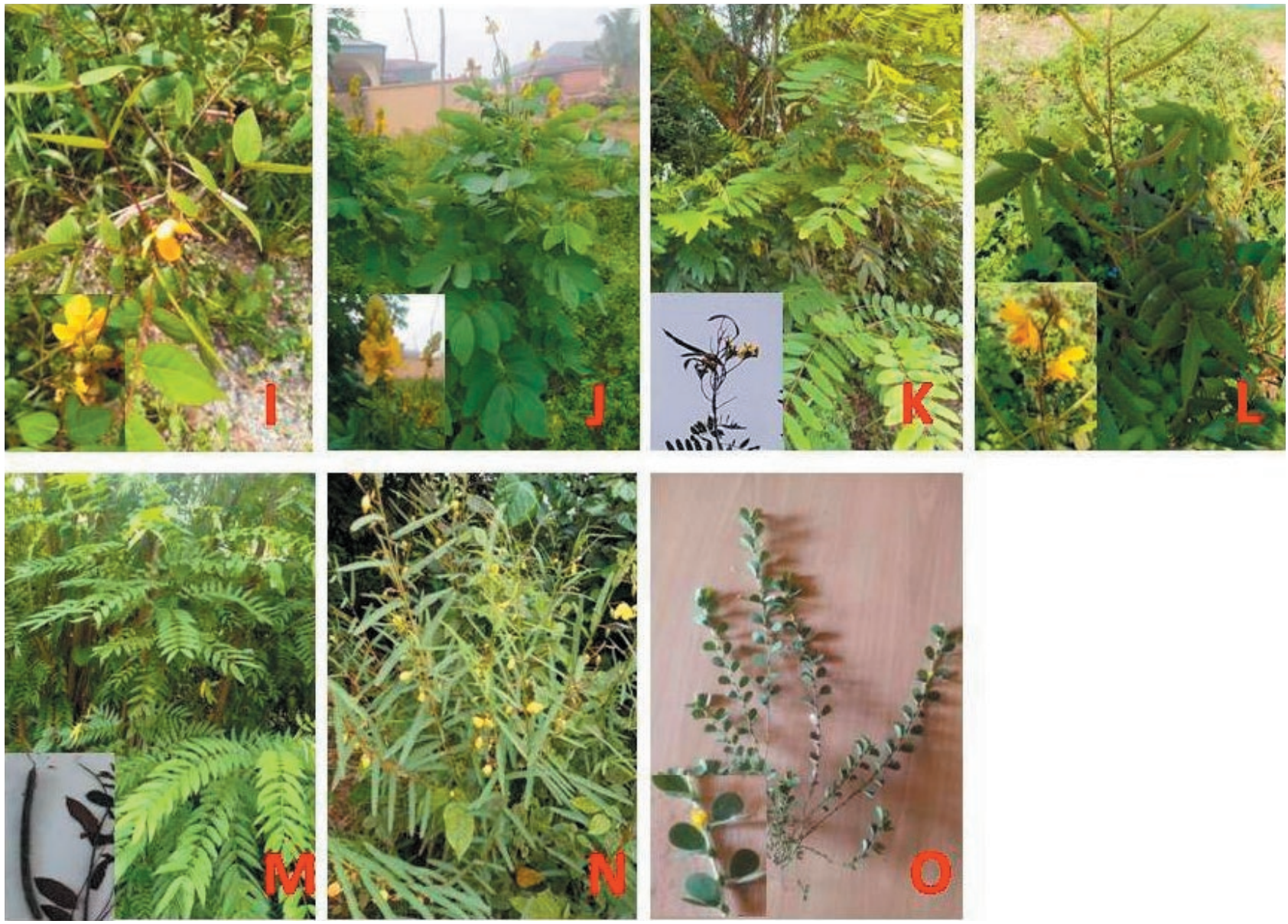

Figure 2 cont'd. I-Senna occidentalis, J -Senna podocarpa, K-Senna siamea, L-Senna sophera. M-Senna spectabilis, N-Chamaecrista mimosoides, $\mathbf{O}$-Chamaecrista rotundifolia.

length and the fourth is most highly correlated with pedicel with (Table 6b).

\section{Correlation coefficients for the morphological traits}

The correlation coefficients for the morphological characters in the species studied are presented in Table 7. The results clearly showed that leaflet length is significantly positively correlated at $\mathrm{p}<0.01$ with leaflet width $(r=0.941)$, petiole length $(r=0.798)$, ratio of petiole length and width $(r=0.394)$, fruit length $(r=$ $0.580)$, fruit width $(r=0.761)$, ratio of fruit length and width $(r=0.290)$ and pedicel width $(r=0.208)$. Similarly, the results showed that leaflet length is significantly negatively correlated at $\mathrm{P}<0.01$ with the ratio of leaflet length and width $(r=-0.449)$ and the ratio of pedicel length and width $(r=-0.263)$. Negative but non-significant correlation exists between leaflet length and petiole width $(r=-0.127)$, pedicel length $(r=-0.111)$.
Significantly positive correlation at $\mathrm{p}<0.01$ also exists between leaflet width and petiole length $(\mathrm{r}=$ $0.848)$, ratio of petiole length and width $(r=0.332)$, fruit length $(r=0.532)$, fruit width $(r=0.692)$, ratio of fruit length and width $(\mathrm{r}=0.283)$ and pedicel width $(\mathrm{r}$ $=0.240$ ). The results show that leaflet width is significantly negatively correlated at $\mathrm{P}<0.01$ with ratio of leaflet length and width $(r=-0.526)$ and ratio of pedicel length and width $(r=-0.186)$. Negative correlation exists between leaflet width and pedicel length $(r=-0.070)$; also positive correlation exists between leaflet width and petiole width $(r=0.017)$.

Significantly negative correlation at $\mathrm{P}<0.01$ exists between ratio of leaflet length and width and petiole length $(r=-0.497)$, petiole width $(r=-0.352)$, ratio of petiole length and width $(r=-0.341)$, fruit length ( $\mathrm{r}$ $=-0.2950)$, ratio of fruit length and width $(r=-0.366)$ and pedicel length $(r=-0.497)$. Also, significantly negative correlation at $\mathrm{P}<0.05$ exists between ratio of leaflet 

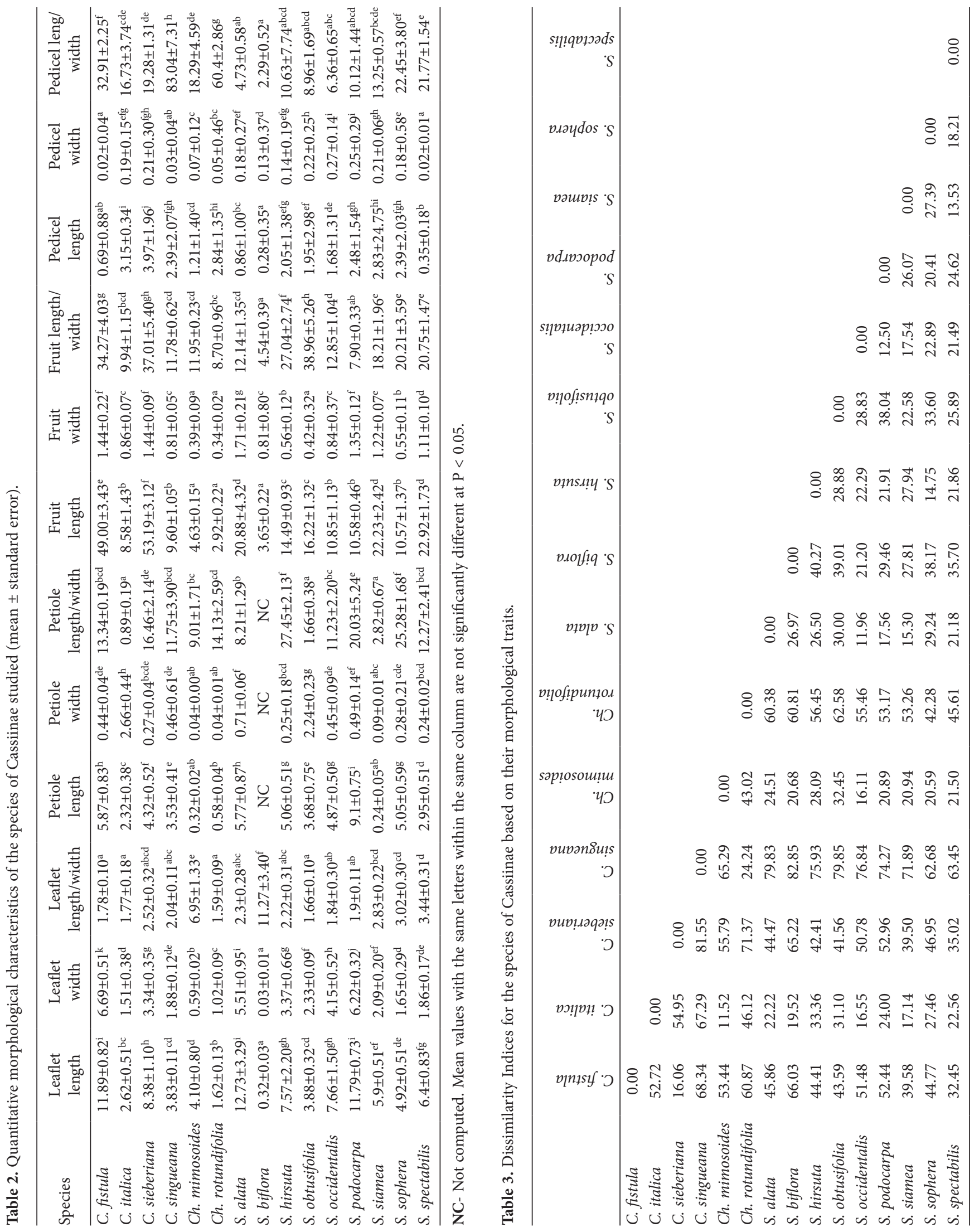


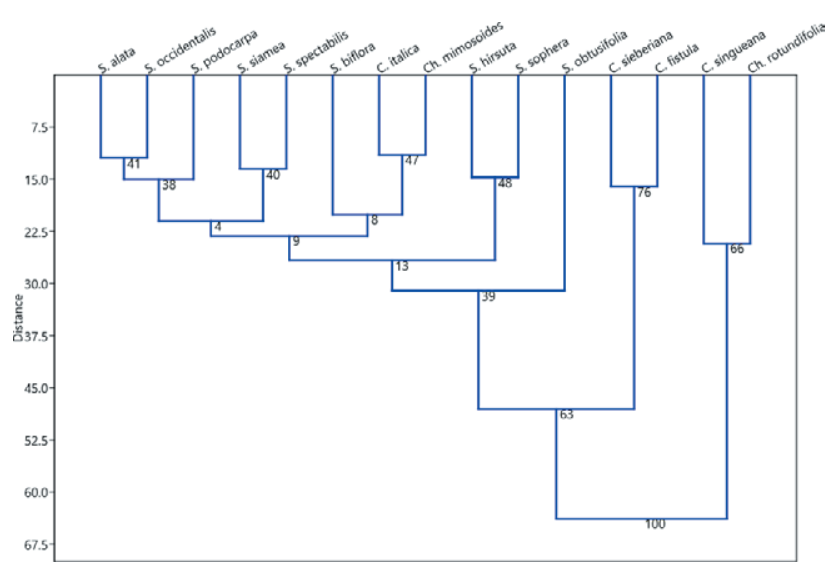

Figure 3. Dendrogram of Cassinae species studied based on Unweighted Pair Group Method with Arithmethic Mean (UPGMA).

Table 4. Agglomeration schedule of the studied species of subtribe Cassiinae as viewed from the perspective of clusters on morphological characters.

\begin{tabular}{lccc}
\hline \multirow{2}{*}{ Stage } & \multicolumn{2}{c}{ Cluster Combined } & \\
\cline { 2 - 3 } & Cluster 1 & Cluster 2 & \\
\hline 1 & 2 & 5 & 132.743 \\
2 & 7 & 11 & 142.963 \\
3 & 13 & 15 & 183.061 \\
4 & 9 & 14 & 217.529 \\
5 & 7 & 12 & 232.285 \\
6 & 1 & 3 & 257.891 \\
7 & 2 & 8 & 404.332 \\
8 & 7 & 13 & 456.309 \\
9 & 2 & 7 & 562.417 \\
10 & 4 & 6 & 587.472 \\
11 & 2 & 9 & 748.365 \\
12 & 2 & 10 & 986.341 \\
13 & 1 & 2 & 2375.399 \\
14 & 1 & 4 & 4225.493 \\
\hline
\end{tabular}

1- C. fistula, 2- C. italica, 3- C. sieberiana, 4- C. singueana, 5- Ch. mimosoides, 6- Ch. rotundifolia, 7- S. alata, 8- S. biflora, 9- S. hirsute, 10- S. obtusifolia, 11- S. occidentalis, 12- S. podocarpa, 13- S. siamea, 14- S. sophera, 15- S. spectabilis

length and width and fruit width $(\mathrm{r}=-0.180)$ and ratio of pedicel length and width $(r=-0.279)$. Pedicel length is significantly positively correlated with pedicel width $(r=0.414)$ and ratio of pedicel length and width $(r=$ $0.237)$ at $\mathrm{P}<0.01$. Fruit length is significantly positively correlated with fruit width $(\mathrm{r}=0.654)$ and ratio of fruit length and width $(\mathrm{r}=0.743)$ at $\mathrm{P}<0.05$.

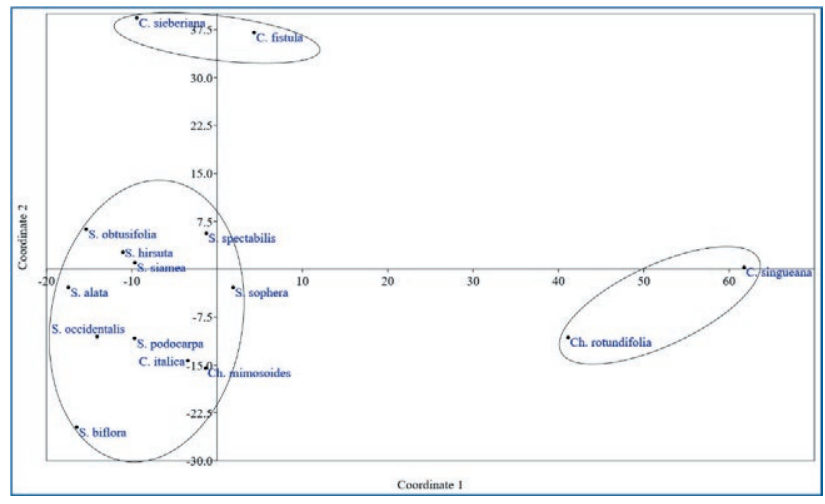

Figure 4. Scatter plot of species of Cassiinae studied based on the quantitative morphological characters after the first and second principal coordinate analyses (PCoA).

Table 5. Variance in the observed morphological traits using Principal Component Analysis.

\begin{tabular}{|c|c|c|c|c|c|c|}
\hline \multirow{2}{*}{$\begin{array}{l}\text { Compo- } \\
\text { nents }\end{array}$} & \multicolumn{3}{|c|}{ Initial Eigenvalues } & \multicolumn{3}{|c|}{$\begin{array}{c}\text { Extraction Sums of Squared } \\
\text { Loadings }\end{array}$} \\
\hline & Total & $\begin{array}{c}\% \text { of } \\
\text { Variance }\end{array}$ & $\begin{array}{l}\text { Cumula- } \\
\text { tive } \%\end{array}$ & Total & $\begin{array}{c}\% \text { of } \\
\text { Variance }\end{array}$ & $\begin{array}{l}\text { Cumula- } \\
\text { tive } \%\end{array}$ \\
\hline 1 & 4.428 & 36.901 & 36.901 & 4.428 & 36.901 & 36.901 \\
\hline 2 & 1.948 & 16.232 & 53.133 & 1.948 & 16.232 & 53.133 \\
\hline 3 & 1.903 & 15.859 & 68.992 & 1.903 & 15.859 & 68.992 \\
\hline 4 & 1.387 & 11.558 & 80.550 & 1.387 & 11.558 & 80.550 \\
\hline 5 & .995 & 8.294 & 88.843 & & & \\
\hline 6 & .822 & 6.847 & 95.690 & & & \\
\hline 7 & .234 & 1.952 & 97.642 & & & \\
\hline 8 & .153 & 1.277 & 98.920 & & & \\
\hline 9 & .076 & .635 & 99.555 & & & \\
\hline 10 & .034 & .284 & 99.839 & & & \\
\hline 11 & .013 & .111 & 99.949 & & & \\
\hline 12 & .006 & .051 & 100.000 & & & \\
\hline
\end{tabular}

\section{DISCUSSION AND CONCLUSIONS}

Morphometrics adds to species descriptions using quantitative elements, allowing more rigorous comparisons within a genus (Kolawole et al. 2016), and it has extensively been employed in many studies (Soladoye et al. 2010b; Deshmukh 2011; Rahman et al. 2013; Zhigila et al. 2015). In the present study, we employed numerical methods in understanding the relationship between members of the tribe Cassinae in Nigeria. Our Findings revealed marked differences in the vegetative and reproductive characters, and were important in the delimitation of the studied taxa. 
Table 6a Component Matrix of examined characters.

\begin{tabular}{lcccc}
\hline & \multicolumn{4}{c}{ Component } \\
\cline { 2 - 5 } & 1 & 2 & 3 & 4 \\
\hline Leaflet length & .931 & -.212 & -.181 & -.108 \\
Leaflet width & .928 & -.106 & -.121 & -.115 \\
Leaflet length/width & -.613 & -.324 & -.581 & .026 \\
Petiole length & .854 & .015 & .042 & -.369 \\
Petiole width & .048 & .793 & -.012 & .244 \\
Petiole length/width & .436 & -.329 & .488 & -.488 \\
Fruit length & .698 & -.167 & .040 & .627 \\
Fruit width & .710 & -.185 & -.378 & .177 \\
Fruit length/width & .498 & .118 & .234 & .618 \\
Pedicel length & .130 & .574 & .589 & -.071 \\
Pedicel width & .319 & .733 & -.330 & -.330 \\
Pedicel length/width & -.216 & -.326 & .789 & .086 \\
\hline
\end{tabular}

Extraction Method: Principal Component Analysis.

4 components extracted.a

Table 6b. Rotated Component Matrix of examined characters.

\begin{tabular}{lcccc}
\hline & \multicolumn{4}{c}{ Component } \\
\cline { 2 - 5 } & 1 & 2 & 3 & 4 \\
\hline Leaflet length & .905 & .343 & -.095 & .108 \\
Leaflet width & .876 & .333 & .019 & .143 \\
Leaflet length/width & -.426 & -.272 & -.746 & .078 \\
Petiole length & .892 & .076 & .227 & .113 \\
Petiole width & -.260 & .210 & .498 & .575 \\
Petiole length/width & .648 & -.198 & .262 & -.496 \\
Fruit length & .344 & .887 & -.017 & -.060 \\
Fruit width & .589 & .483 & -.287 & .225 \\
Fruit length/width & .099 & .782 & .277 & -.018 \\
Pedicel length & -.025 & -.002 & .835 & .026 \\
Pedicel width & .268 & -.178 & .331 &. $\mathbf{8 0 2}$ \\
Pedicel length/width & -.189 & .012 & .311 & -.806 \\
\hline
\end{tabular}

Extraction Method: Principal Component Analysis. Rotation Method: Varimax with Kaiser Normalization.

Rotation converged in 9 iterations.

The species exhibited significant morphological variations. Leaflet length was highest in S. alata and least in Ch. mimosoides, while the width was highest in C. fistula and least in Ch. mimosoides. Interestingly, the highest and smallest leaflet length/width ratios were observed in the twin-taxa - Ch. mimosoides and Ch. rotundifolia respectively. While petiole was longest in $S$. podocarpa $(9.1 \mathrm{~cm})$, it was shortest in $S$. siamea $(0.24 \mathrm{~cm})$. Generally, the fruits were considerably long ( $\geq 10 \mathrm{~cm}$ long) except in C. italica, S. singueana, Ch. mimosoides, Ch.

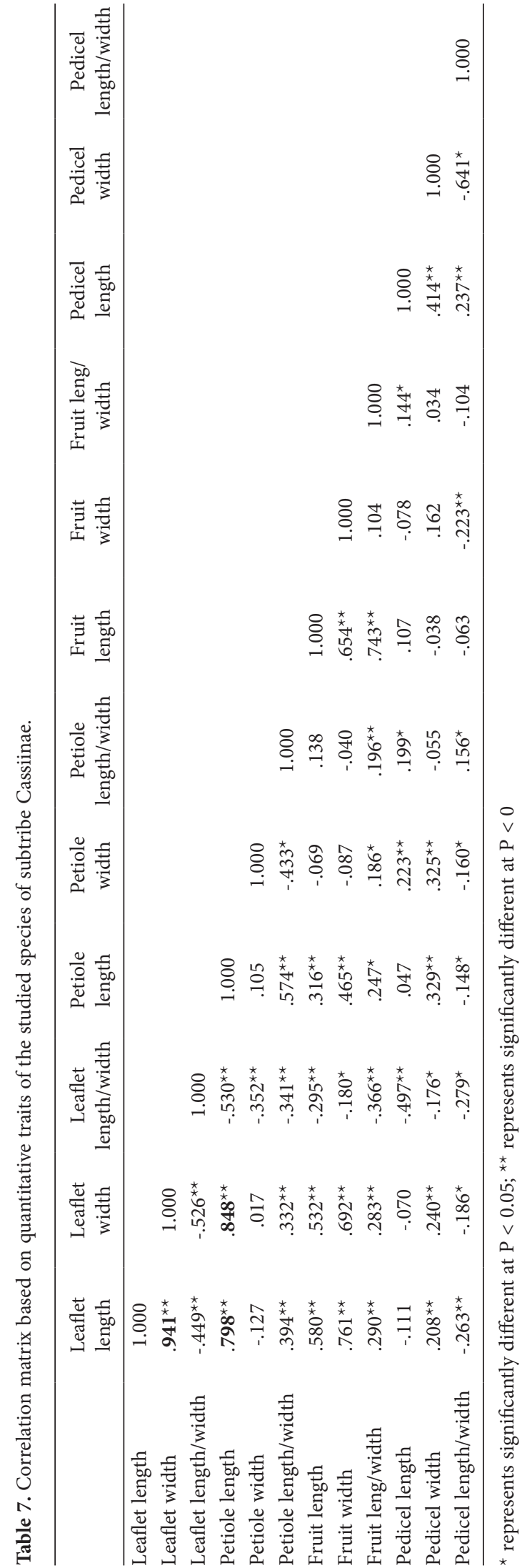


rotundifolia, and S. biflora where they were shorter $(<10$ $\mathrm{cm})$. The fruit size and pedicel length are dependent on the age of plants as earlier noted by other reports (Irvine 1961; Burkill 1995; Kolawole et al. 2016). Leaf shape and size also varies within the same plant stand. Nwachuwu and Mbagwu (2006) thought that such variations observed may be due to environmental as well as genetic factors and the interaction among them. Nevertheless, previous studies suggested that light intensity may affect the carbohydrate balance, which could affect the length of the cells in the direction of the long axis, thereby leading to differences in the length, shapes, and width of the leaves (Soladoye et al. 2010a; Kolawole et al. 2016).

In our study, leaflet length was significantly positively correlated at $\mathrm{P}<0.01$ with characters such as leaflet width, petiole length, ratio of petiole length and width, fruit length, fruit width, ratio of fruit length and width, and pedicel width. Similarly, leaflet width showed high positive correlations with petiole length, fruit length, and fruit width respectively. Nevertheless, there exist negative correlations between leaflet length and leaflet length/width ratio, leaflet length and petiole width, leaflet length and pedicel length, leaflet width and leaflet length/width ratio, petiole length and pedicel length/with ratio. Previous related studies on the genus Ficus had shown highly significant positive correlations between leaf length and leaf width, leaf length and lamina length, leaf length and petiole length, lamina length and lamina width; and negative correlations between leaf width and leaf length/width ratio, petiole length and fruit length/petiole length ratio Sonibare et al. (2004). Jeruto et al. (2017) in their study on Senna didymobotrya also reported high positive correlations between plant height and stem height, pod length and pod width, leaf number and leaflet number, leaflet length and leaflet width, inflorescence length and inflorescence length of the basal stalk (peduncle). These amongst others, are supporting evidences for the application and relevance of morphometrics in taxonomic studies.

Results from the PCA analysis showed that only four components accounted for $80.5 \%$ of the total variance. The first component contributed $36.9 \%$, the second contributed $16.2 \%$, the third had $15.8 \%$ while the fourth had $11.6 \%$. However, the other 8 components collectively accounted for the remaining $19.5 \%$ and produced insignificant contributions to the delimitation of the taxa studied. In furtherance, cluster analysis from our findings revealed the infra-specific relationship between the 15 species of Cassiinae studied, based on the quantitative morphological traits evaluated. There is a greater affinity between C. italica and Ch. mimosoides. These two species seem not to be easily separated as shown in the den- drogram and further supported by the distance measure (coefficients of cluster) revealed through the agglomeration schedule. This trend also follows for $S$. alata and S. occidentalis, S. alata and S. podocarpa, S. siamea and S. spectabilis, S. hirsuta and S. sophera, and likewise $C$. fistula and C. sieberiana. While S. singueana and Ch. rotundifolia occupy an isolated position towards the bottom of the scatter plot, C. fistula and C. sieberiana also co-exist in the upper left of the plot, and others are clustered together in a more central position; hence dividing the studied taxa into three clusters. Observations also showed less dissimilarity coefficients between $C h$. mimosoides and C. italica, S. alata and S. occidentalis, S. occidentalis and S. podocarpa, S. alata and S. podocarpa, S. siamea and S. spectabilis, S. hirsuta and S. sophera, S. fistula and S. sieberianna, thus reflecting their morphological similarities.

It is noteworthy that the affinity between $S$. alata and $S$. podocarpa as evidenced in this study, supports the folklore claims in south-western Nigeria that they are closely related. According to this belief, $S$. alata is the foreign species while $S$. podocarpa is regarded a native species to Nigeria. Also, a similar result had been observed in the pollen morphological studies of these two species as their pollens are not easily separated by light microscope (Kolawole 2017). A close association of the species of the genus Senna in the first cluster is in agreement with the previous findings of Saheed and Illoh (2011), Ogundipe et al. (2009) and Rahman et al. (2013) who reported that they are taxonomically related. Ecologically, the species studies are sympatric in distribution, extending from the southern part of Nigeria to the drier areas in the north, but more abundant across the transitional equatorial region which receives more rainfall than other regions within the study area.

However, with the continuous human induced anthropogenic activities in the area, there is a high tendency of further reduction in the distribution of the species in the near future if conservation strategies are not rapidly developed and implemented. Such strategies would also checkmate the gradual but eventual loss of our endangered and threatened species, especially the overexploited.

The present study has added to the understanding of Cassiinae species in Nigeria, through the application of numerical taxonomy. Findings showed that despite the overlapping nature of the quantitative morphological traits examined, the species can still be distinguished from each other using certain characters. Our study also further supports the creation of Chamaecrista and Senna from the old Cassia. Nevertheless, while the relevance of molecular characters has been witnessed in recent taxo- 
nomic studies, we strongly suggest that the use of morphological characters should not be ignored as it formed the basis for traditional taxonomy, and as evidenced in most of the classification systems used up to this date.

\section{ACKNOWLEDGMENTS}

The authors are grateful to the management of Forest Herbarium Ibadan (FHI) and the University of Ilorin Herbarium, for the free access to herbarium specimens consulted during this study.

\section{REFERENCES}

Airy-Shaw HK. 1973. A dictionary of the flowering plants. 8th edition, Cambridge University Press, London. pp. 1246.

Akinremi AA, Omobuwajo OR, Elujoba AA. 2000. Pharmacological standards for the fruits of Cassia fistula and C. podocarpa. Nigerian Journal of Natural Products and Medicine. 4: 23-27.

Bateman RM, Rudal PJ. 2006. Evolutionary and morphometric implications of morphological variation among flowers within an inflorescence: A case-study using European orchids. Annals of Botany. 98: 975993.

Bentham G. 1871. Revision of the genus Cassia Linn. Transaction of Linnean Society. 27: 503-591

Bookstein FL, Chernoff B, Elder R, Humphries J, Smith G, Strauss R. (eds.) 1985. Morphometrics in Evolutionary Biology. Philadelphia, PA: Philadelphia Academy of Natural Sciences.

Boonkerd T, Pechsri S, Baum BR. 2005. A phenetic study of Cassia sensu lato (Leguminosae-Caesalpinioideae: Cassieae: Cassiinae) in Thailand. Plant Systematics and Evolution. 252(3\&4): 153-165.

Bradley PR. 1992. British Herbal Compendium, Vol.1. British Herbal Medicine Association, Bournemouth.

Burkill HM. 1995. The Useful Plants of West Tropical Africa, Ed 2, Vol. 3, Royal Botanic Gardens, Kew. London. pp: 150-167.

Chukwuma EC, Ayodele AE, Soladoye MO, Chukwuma DM. 2016. Numerical taxonomy of Berlinia species (Caesalpinioideae: Leguminosae) and their distribution in Nigeria. Journal of Threatened Taxa. 8(2): 8443-8451.

Davis PH, Heywood VH. 1963. Pricinples of Angiosperm Taxonomy. Oliver and Boyd, Edinburgh. pp. 558.

Deshmukh SA. 2011. Morphometrics of genus Cassia L. from Kolhapur District. The Bioscan. 6(3): 459-462.
Elujoba AA, Abere AT, Adelusi SA. 1999. Laxative activities of Cassia pods sourced from Nigeria. Nigerian Journal of Natural Products and Medicine. 3: 51-53.

Forey P, MacLeod N. 2002. Morphology, Shape and Phylogeny. Systematics Association Special Vol. 64. Taylor and Francis, London. pp. 100-138.

Holmgren PK, Keuken W, Schofield EK. 1990. Index Herbariorum Part I. The Herbaria of the World. 8th ed. Reg. Veg., - New York. Also available and updated at: http://sweetgum.nybg.org/science/ih/

Hou D, Larsen K, Larsen S S. 1996. Caesalpiniaceae. In: Kalkman C, Stevens P. F, Kirkup D W, deWilde WJJO, Nooteboom HP. (eds.) Flora Malesiana. Vol. 12, part 2. Rijksherbarium/ Hortus Botanicus, Leiden. pp. 681-690.

Hutchinson J, Dalziel JM. 1958. Flora of West Tropical Africa. Vol I. Part 2. The Whitefraius Press Ltd, London. pp. 544.

Irwin HS, Barneby RC. 1982. The American Cassiinae. A synoptic revision of Leguminosae tribe Cassieae subtribe Cassiinae in the New World. Memoirs of New York Botanic Gardens. 35(1): 1-918.

Irwin HS, Barneby RC. 1981. Cassieae. In: Advances in Legume Systematics (R. M. Polhill and P. H. Raven Eds) Royal Botanical Gardens, Kew. Part 1: 97-106.

Irwin HS, Turner BL. 1960. Chromosomal relationship and taxonomic consideration in the genus Cassia. American Journal of Botany. 47: 309-318.

Jensen RJ. 2003. The conundrum of morphometrics. Taxon. 52: 663-671.

Jeruto P, Arama P, Anyango B, Nyunja R, Taracha C, Opiyo S. 2017) Morphometric study of Senna didymobotrya (Fresen.) H.S. Irwin and Barneby in Kenya. Journal of Natural Sciences Research. 6(7): 54-69.

Kent M, Coke P. 1992. Vegetation Description and Analysis: A Practical Approach. John Wiley, New York. pp. 428.

Kolawole OS. 2017. Taximetric study of species of subtribe Cassiinae in selected states of Nigeria. $\mathrm{PhD}$ Thesis. University of Ilorin, Ilorin. pp. 233. (Unpublished).

Kolawole OS, Abdulrahaman AA, Jimoh MA, Oladele FA. 2016. Morphometric study of several species of the genus Jatropha Linn. (Euphorbiaceae). Notulae Scientia Biologicae. 8(2): 211-215.

Larsen K. 1993. Note on the nomenclature of Cassieae (Leguminosae: Caesalpinioideae) in Malaysia. Nordic Journal of Botany. 13(4): 403-404.

Larsen K, Larsen SS, Vidal JE. 1984. Leguminosae- Caesalpinioideae. In: Smitinand T, Larsen K. (eds.) Flora of Thailand 4(1): 102-123. Forest Herbarium, Royal Forest Department, Bangkok. 
Lock JM. 1988. Cassia s.l. (Leguminosae- Caesalpinioideae) in Africa. Kew Bulletin. 43(2): 333-342.

Mabberley DJ. 1997. The Plant-Book. A Portable Dictionary of the Vascular Plants. Cambridge University Press, New York. pp. 858.

Nwachukwu CU, Mbagwu FN. 2006. Morphological features in some species of Indigofera L (LeguminosaePapilionoideae). Journal of Fisheries International. 1 (2-4): 50-54.

Ogundipe OT, Kadiri AB, Adekanmbi OH. 2009. Foliar epidermal morphology of some Nigerian species of Senna (Caesalpiniaceae). Indian Journal of Science and Technology. 2(10): 5-9

Pandey SN, Misra SP. 2009. Taxonomy of Angiosperms. Ane Books Pvt. Ltd. Parwana Bhawa, Darya Ganj, New Delhi, India. pp. 256-259.

Rahman MO, Rahman MZ, Ayesa B. 2013. Numerical taxonomy of the genus Senna Mill. from Bangladesh. Bangladesh Journal of Plant Taxonomy. 20(1): 77-83.

Saheed SA, Illoh HC. 2011. Important morphological characters in several species of Cassiinae (Leguminosae) in South-Western Nigeria. Notulae Scientia Biologicae. 3(2):47-56

Saheed SA, Illoh HC. 2010. A taxonomic study of some Species in Cassiinae (Leguminosae) using leaf epidermal characters. Notulae Botanicae Horti Agrobotanici Cluj-Napoca. 38(1):21-27.

Silva O, Barbosa S, Diniz A, Valdeira ML, Gomes E. 1997. Plant extracts antiviral activity against herpes simplex virus type I and African swine fever virus. International Journal of Pharmacognosy. 35(10): 12-16.

Singh V. 2001. Monograph on Indian subtribe Cassiinae (Caesalpiniaceae). Jodhpur, Scientific, pp. 278

Soladoye MO, Sonibare MA, Chukwuma EC. 2010a. Morphometric study of the genus Indigofera L. (Leguminosae-Papilionoideae) in South-Western Nigeria. International Journal of Botany. 6(3): 343-350.

Soladoye MO, Onakoya MA, Chukwuma EC, Sonibare MA. 2010b. Morphometric study of the genus Senna (Mill) in South-Western Nigeria. African Journal of Plant Science. 4(3): 044-052.

Soladoye MO, Sonibare MA, Rosanwo TO. 2008. Phytochemical and morphometric analysis of the genus Acalypha Linn. (Euphorbiaceae). Journal of Applied Sciences. 8: 3044-3049.

Sonibare MA, Jayeola AA, Egunyomi A. 2004. A morphometric analysis of the genus Ficus Linn. (Moraceae). African Journal of Biotechnology. 3: 229-235.

Sultana S, Khan MA, Ahmad M, Bano A, Zafar M, Shinwari V. 2011. Authentication of herbal medicine neem (Azadirachta indica A. Juss.) by using taxo- nomic and Pharmacognostic techniques. Pakistan Journal of Botany (Special Issue). 43: 141-150

Wiens JJ. 2000. Phylogenetic Analysis of Morphological Data. Smithsonian Institution. Washington, DC, pp. 220

Yousuf Z, Shinwari ZK, Qureshi RA, Perveen A. 2008. Leaf epidermal anatomy of selected Allium species, family Alliaceae from Pakistan. Pakistan Journal of Botany. 40(1): 77-90.

Zhigila DA, Sawa FB.J, Abdul SD. 2015. Morphometric study of accessions of Sesamum indicum L. collected from Nigeria. African Journal of Plant Science. 9(2): 56-64. 